\title{
Timeliness of Financial Reporting in Emerging Capital Markets: Evidence from Turkey
}

\author{
Asli Gunduzay TÜREL ${ }^{*}$
}

\section{Introduction}

The objective of financial statements is to provide information about the entity that is useful to a wide range of users in decision making. In order to be useful for decision making, financial statements should be understandable, relevant, reliable, and comparable. Timeliness of financial statements is one of the important determinants of their relevance. Irrespective of whether one chooses to call timeliness an objective of accounting or an attribute of useful accounting information, it is clear that both the disclosure regulations and a large part of the accounting literature adopt the premise that timeliness is a necessary condition to be satisfied if financial statements are to be useful.

Timely financial reporting is an essential ingredient for a wellfunctioning capital market. Undue delay in releasing financial statements increases uncertainty associated with investment decisions. The increase in the delay reduces the information content and relevancy of the information. Entities should balance the relative benefits of timely reporting with the reliability of information provided in the financial statements. To provide information on a timely basis it may often be necessary to report before all aspects of a transaction or other event are known, thus impairing reliability. Conversely, if reporting is delayed until all aspects are known, the information may be highly reliable but of little use to users who have had to make decisions in the interim.

This paper empirically examined the relationship between the timeliness and both company specific and audit related factors in a developing country, Turkey. The objectives of this study are two-fold.

Asli Gunduzay Türel, Ph.D. - Istanbul University Avcilar Kampusu Isletme Fakultesi Muhasebe Anabilim Dali, Avcilar, Istanbul, Turkey; <gunduzay@istanbul.edu.tr>. 
Türel, A. G.: Timeliness of Financial Reporting in Emerging Capital Markets: Evidence from Turkey.

First, to measure the extend of timeliness in a developing country, Turkey. Second, to establish the impact of both company specific and audit related factors on timeliness of financial reporting in Turkey. This study may be the first which attempts to establish the association between both company specific and audit related factors and the timeliness in Turkey. In order to meet these objectives, first, we determine the companies that report at the regulatory deadline that report before the regulatory deadline, and that report after the regulatory deadline. Next, we investigate the effects of both company specific and audit related factors such as company size, sign of income, industry, audit opinion, and auditor firm on timely financial reporting practices.

\section{The Regulatory Framework for Timely Reporting in Turkey}

The reporting obligations of Turkish listed companies relating to timeliness of annual financial statements are found in two regulatory sources issued by the Turkish parliament: (i) Turkish Commercial Code, 1956 (Turk Ticaret Kanunu, 1956) and (ii) Law of Capital Market. The Turkish Commercial Code was published in the Official Journal dated 29 June 1956 and numbered 9353. Turkish Commercial Code (clause 327) requires annual reports be prepared at least 15 days before the date of the annual general meeting.

The communiqué "Rules and Principles Related to Financial Statements in the Capital Market" included in the Law of Capital Market is the other regulatory source that obliges companies to publish financial statements in a defined period of time. This communiqué was enacted in 1989. Capital Market Board (CMB) of Turkey published several communiqués related to financial reporting between 1989 (SPK, 1989) and 2003. There were no changes related to timeliness of financial statements in these communiqués. In 2003, the Board issued a broad set of financial reporting standards that are mostly compatible with IASs and IFRSs (SPK, 2003). These standards became effective for listed companies from the beginning of 2005. In order to make harmonization of accounting standards within the country, CMB of Turkey abolished its accounting standards by issuing a communiqué in 2008 (SPK, 2008). Currently, Turkish Accounting Standards Board (TASB) is the only organization that published accounting standards which are compatible with IASs and IFRSs. 
According to communiqué enacted in 1989, companies that are listed on the stock-exchange must publish their audited annual financial statements by the 10th week after their financial year-end. According to communiqué enacted in 2003, separate financial statements must be published within 10 weeks of the financial year-end and consolidated financial statements must be published within 14 weeks of the financial year-end.

\section{Review of the Relevant Literature}

Timeliness requires that information should be made available to financial statement users as rapid as possible and it is a necessary condition to be satisfied if financial statements are to be useful. It has been argued that the shorter the time between the end of the accounting year and publication date, the more benefit can be derived from the audited annual reports. However, it is not possible to release annual reports unless it is certified as accurate by professional chartered accountant(s). One of the most material reasons for late publication of annual reports by public limited companies is that the accounts need to be audited before the release of financial statements. Time lag in financial report release and audit delay are intertwined and used interchangeably in financial reporting literature. As a result, in many cases timeliness has been studied together with actually dealt with audit delays (Hossain et al., 1998).

The existing literature on timeliness and audit delay is very extensive. Most of these studies have been focused on the timeliness of corporate and audit reports. There are studies which empirically examined the relationship between the audit delay/timeliness and several company characteristics and audit related factors in the developed countries as well as in developing countries. These studies are carried out in the US, Australia, Canada, Spain, New Zealand, France, Greece, China, Bangladesh, India and Pakistan.

During the last four decades, the literature on timeliness in general has become an established area of research in financial accounting. Here, some of these studies are reviewed which facilitates background to formulate the hypotheses which have been used in this study.

Bonson-Ponte et al. (2008) analyzed the factors that determine delays in the signing of audit reports on the Spanish continuous market for the period from the year 2002 to the year 2005. They found that classification 
Türel, A. G.: Timeliness of Financial Reporting in Emerging Capital Markets: Evidence from Turkey.

to sectors that are subject to regulatory pressure (financial and energy sector) and the size of company affect the audit delay. Variables such as audit firm, qualifications or regulatory change show no significant relationship with audit delay in Spain. The results show that the companies of larger relative size sign the audit report in fewer days. Also the companies classified to sectors that are regulated internally and are subject to regulatory pressures also sign the audit report before those companies that belong to sectors that are not regulated.

Owusu-Ansah and Leventis (2006) investigated the factors that affect timely annual financial reporting on the Athens Stock Exchange. The results indicate that large companies, service companies and companies audited by the former Big-5 audit firms have shorter final reporting leadtime. According to the results companies in the construction sector, companies whose audit reports were qualified and companies that had a greater proportion of their equity shares directly and indirectly held by insiders do not promptly release their audited financial statements.

Ahmad and Kamarudin (2003) investigated the determinants of audit delay in the Kuala Lumpur Stock Exchange during the period 1996-2000. The results suggests that the audit delay is significantly longer for companies classified as non-financial industry, receiving other than unqualified audit opinions, incurring losses and having higher risk. Financial companies and companies audited by the Big-5 tend to have a shorter audit delay.

Owusu-Ansah (2000) analyzed the timeliness of annual reports on the Zimbabwe Stock Exchange in 1994. The results of the analysis indicate that $98 \%$ of the companies in the sample reported promptly to the public. Also the results show that company size, profitability and company age as statistically significant explanators of the differences in the timeliness of annual reports in Zimbabwe.

Haw and $\mathrm{Wu}$ (2000) examined the relation between firm performance and the timing of annual report releases by listed Chinese firms for the period from the year 1994 to the year 1997. They found that good news firms release their annual reports earlier than bad news firms, and loss firms release their annual reports the latest.

Hossain and Taylor (1998) examined the relationship between the audit delay and several company characteristics in Pakistan in 1993. The 
corporate attributes examined in this study are size of the company, debtequity ratio, profitability, subsidiaries of multinational companies, audit fee, industry type and audit firm size. The results showed that audit delay was significantly related to the subsidiaries of multinational companies only.

Carslaw and Kaplan (1991) analyzed the determinants of audit delay in New Zealand for the period from the year 1987 to the year 1988. The results suggested that both company size and sign of income significantly affect audit delay far the two years examined. According to the results, there was a negative association between the audit delay and company size and also the audit delay and the sign of income.

Ashton et al. (1989) examined the determinants of audit delay on the Toronto Stock Exchange from 1977 to 1982. The results indicate that company size is inversely related to audit delay. They also indicate that financial service companies, as well as companies with year-ends in their "busy season" have shorter delays. And also Big-9 auditors are consistently associated with shorter audit delays than are smaller auditing firms.

Ashton et al. (1987) analyzed the determinants of audit delay in USA in 1982. They found that audit delay is significantly longer for companies that receive qualified audit opinions, are in the industrial as opposed to financial industry classification, are not publicly traded and have a fiscal year-end other than December, have weaker internal controls, employ less complex data-processing technology, and have a greater relative amount of audit work performed after year-end.

Most of the prior studies have focused primarily on developed markets. To date, rare studies have systematically examined the relative effects of factors on timely reporting behavior of companies in emerging economies. The present study contributes to the literature by providing such evidence.

\section{Research Methodology}

\subsection{Aim of the Research}

The aim of this research is to investigate the effects of both company specific and audit related factors such as company size, sign of income, industry, audit opinion, and auditor firm on timely financial reporting practices for companies listed on Istanbul Stock Exchange (ISE). 
Türel, A. G.: Timeliness of Financial Reporting in Emerging Capital Markets: Evidence from Turkey.

\subsection{Sample Selection and Data Collection}

The sample covers the listed Turkish companies for the year 2007. Because of the need to obtain information from annual reports, the study was restricted to public companies. There were 319 companies listed on the Istanbul Stock Exchange as at 31 December 2007. We chose our sample on the basis of the following criteria. First, we eliminated 102 financial companies because of the major difference between such companies' disclosure requirements and audit procedures and also those companies are subject to additional regulations Second we excluded 5 companies having financial year-end other than 31 December because, as suggested in the literature, the month of financial year-end influences timely reporting behavior. Third 1 company was excluded because of lack of audit report. The final sample consists of 211 companies, representing about $66 \%$ of all companies listed on the market. Table 1 reports the sampling design. In our sample companies, six of the audit reports were dated as 2007 but we assume that it was written by mistake so we count them as a sample.

Tab. 1: Summary of Sample Criteria

\begin{tabular}{|l|r|r|}
\hline Description & $\begin{array}{c}\text { No. of Listed } \\
\text { Companies }\end{array}$ & $\begin{array}{c}\text { Percentage of } \\
\text { Total Population }\end{array}$ \\
\hline $\begin{array}{l}\text { Companies listed on ISE as of 31 } \\
\text { December 2007 }\end{array}$ & 319 & 100.00 \\
\hline Deduct: & & \\
\hline Companies in the financial sector & 102 & 31.97 \\
\hline $\begin{array}{l}\text { Companies with financial year-end other } \\
\text { than December }\end{array}$ & 5 & 1.57 \\
\hline $\begin{array}{l}\text { Companies lacking some data of interest } \\
\text { Companies with usable data (the sample } \\
\text { size) }\end{array}$ & 211 & 0.31 \\
\hline
\end{tabular}

Source: author's own presentation.

The data for each of the 211 sample companies were taken from their annual reports. Using 211 company reports from the ISE companies during 2007, this paper analyses the timeliness of financial reports by first determining the reporting lags, and then by using a multivariate regression to identify the determinants of reporting lags. 


\subsection{Hypotheses}

To better understand how Turkish companies respond to the timely reporting requirements, it is necessary to relate their timely reporting practices to certain factors. While there may be many factors, company specific and audit related ones have been proposed and tested in prior studies as being particularly important. This study investigates some of these factors that are relevant to the socio-economic conditions in Turkey and for which data were available. The audit related factors include the audit firm (AUDITOR), audit opinion (OPINION), and company specific factors include company size (SIZE), sign of income (INCOME), and industry (INDUSTRY). Therefore, the hypothesis of this study is drawn below;

\section{H1: Reporting lead time is a function of a company's size.}

Company size has been the variable studied most frequently by many studies and measured by the year-end total assets of each company as in prior studies (Abdulla, 1996; Ashton et al., 1989; Carslaw et al., 1991; Courtis, 1976; Davies et al., 1980; Gillings, 1977; Newton, 1989). Most prior studies found a negative association between the audit delay/timeliness and the company size. Both positive and negative relationship can be found between the company size and the lead time of the financial statements. Usually, large companies are timely reporters for several reasons. First, large companies have more resources, more accounting staff, and sophisticated accounting information systems that result in more timely annual reports. Second, large companies tend to have strong internal control systems with the consequence that auditors spend less time in conducting control tests. Delays are, therefore minimized and this enables the companies to report promptly to the public. Third, large companies tend to be followed by a relatively large number of financial analysts who usually rely on timely release of annual reports to confirm and revise their expectations of companies' present and future economic prospects. And also management may wants to reduce the probability of increased regulative control over their reporting activities. (Larger firms have taken less time to report, which is expected because they are more in the public eye). On contrary, it can be argued that large companies publish their financial statements later than the small ones since the financial transactions in large companies are more complex. In other words, there may be a positive relationship between the size of the company and the lead time. 
Türel, A. G.: Timeliness of Financial Reporting in Emerging Capital Markets: Evidence from Turkey.

\section{H2: Reporting lead time is a function of an auditor.}

Auditors are classified into the Big 4 and the non-Big 4. The Big 4 refers to Pricewaterhouse Coopers, KPMG, Ernst\&Young and Deloitte\&Touche. The Big 4 audit firms are assigned 1 and the others are assigned 0. Most of the prior research about this subject (Ahmad et al., 2003; Ansah et al., 2006; Ansah, 2000; Ashton et al., 1989; Bonson-Ponte et al., 2008; Carslaw et al., 1991; Hossain et al., 1998) investigates whether audited by Big audit firms have any positive effect on the lead time of financial statements. It is expected that the lead time for the Big 4 firms will be lesser than the lead time for the smaller firms. This is because the former are large firms and thus it is assumed that they are able to audit more efficiently and have greater flexibility in scheduling the audits so that it can be completed on time. However, a negative effect can also be expected since the numbers of Big four clients are much more than small auditing firms. In other words, it can be expected that companies that are audited by big four publish their financial statements later than other companies that are audited by small audit firms. Larger audit firms have larger clients, and the latter are more likely to have "ongoing" audits than small companies; or that the larger auditing firms are more efficient. Big 4 firms, because they are larger firms, might be able to audit more efficiently, and have greater flexibility in scheduling to complete audits on a timely basis.

\section{H3: Reporting lead time is a function of sign of income.}

Sign of income is selected as a determinant of timely reporting in most of the studies (Ahmad et al., 2003; Ansah et al., 2006; Ashton et al., 1989; Ashton et al., 1987; Bamber et al., 1993; Carslaw et al., 1991; Hossain et al., 1998). In this study, the companies reporting an income will be assigned 1 whereas the remaining will be assigned 0 . The companies reporting an income for the period are expected to have a shorter lead time compared to the ones reporting a loss. Thus, a negative association is expected between the lead time and the companies reporting an income. Loss announcements take longer to reach to the public than income announcements. It is suggested that earnings announcements containing good news might be advanced and, in particular, that earnings announcements containing bad news tend to be delayed (Givoly et al., 1982). 


\section{H4: Reporting lead time is a function of audit opinion.}

The previous studies suggested that the lead time is an increasing function of the audit opinion (Ahmad et al., 2003; Ashton et al., 1989; Ashton et al., 1987; Bonson-Ponte et al., 2008; Carslaw et al., 1991). The qualified audit opinion is viewed as bad news and thus slows down the reporting process. Companies not receiving standard audit opinions are expected to have a longer lead time compared to the ones receiving a standard (clean) report. In this study, a standard (unqualified) audit opinion will be assigned 1 , and the rest are assigned 0 .

\section{H5: Reporting lead time is a function of industry.}

Industry is selected as a determinant of timely reporting in most of the studies (Ahmad et al., 2003; Ansah et al., 2006; Ashton et al., 1989; Ashton et al., 1987; Carslaw et al., 1991). This study classifies the companies into manufacturing and non-manufacturing industry based on the ISE classification. In this study, the manufacturing companies were coded 1 and others were coded 0 . It is expected that the industry of the companies has effect on the lead time of financial statements. Put another way, the companies in some industries are expected to publish their financial statements earlier than other industries.

\subsection{Model Specification}

As in prior studies, we define "timeliness" as the number of days between a company's financial year-end and the day of the audit report. As in Owusu-Ansah (2000) and in Owusu-Ansah and Leventis (2006), we prefer to use "lead time" instead of "delay", which is generally used in the literature, to denote timeliness. If a company releases its financial statements within regulatory deadline, then, it cannot be said that the company has delayed in releasing its financial statements. Therefore, we describe the number of days that elapses between a company's financial year-end and the date of audit report as its reporting lead time. We computed the lead time for each company by counting the number of days that elapsed between its financial year-end and the date of the audit report.

To investigate the influence of the selected company-specific and audit-related factors on timely reporting behavior of the companies in our 
Türel, A. G.: Timeliness of Financial Reporting in Emerging Capital Markets: Evidence from Turkey.

sample, we estimated the following cross-sectional regression model. Table 2 shows the explanation of the explanatory independent variables.

$$
\begin{aligned}
\text { LEADTIME }= & b_{0}+b_{1} \cdot \text { SIZE }+b_{2} \cdot \text { AUDITOR }+b_{3} \cdot I N C O M E \\
& +b_{4} \cdot \text { OPINION }+b_{5} \cdot \text { INDUSTRY }+e
\end{aligned},
$$

Tab. 2: Definitions of Independent Variables

\begin{tabular}{|l|l|}
\hline $\begin{array}{l}\text { Independent } \\
\text { Variables }\end{array}$ & Explanation \\
\hline SIZE & Total assets of company \\
\hline AUDITOR & $\begin{array}{l}\text { Type of audit firm represented by a dummy variable: } \\
\text { "Big -4 audit firms" assigned a 1, otherwise a 0. }\end{array}$ \\
\hline INCOME & $\begin{array}{l}\text { Sign of current year income represented by a dummy } \\
\text { variable: companies with "positive net income" assigned } \\
\text { a 1, otherwise a 0. }\end{array}$ \\
\hline OPINION & $\begin{array}{l}\text { Type of audit opinion represented by a dummy variable: } \\
\text { "standard opinion" assigned a 1, otherwise a 0. }\end{array}$ \\
\hline INDUSTRY & $\begin{array}{l}\text { Industry classification represented by a dummy variable: } \\
\text { "manufacturing" companies assigned a 1, otherwise a 0. }\end{array}$ \\
\hline
\end{tabular}

Source: author's own presentation.

\section{Results}

\subsection{Summary Statistics}

The reporting obligations relating to timeliness of separate financial statements and consolidated financial statements of Turkish listed companies are different. Separate financial statements must be published not later than 73 days, and consolidated financial statements must be published not later than 101 days after the financial year end. Therefore, the model was tested for two groups separately in terms of descriptive statistics. The lead time of audited financial statements can be seen in Table 3-A and Table 3-B below. 
Tab. 3-A: Pattern of Publication Dates of Separate Audited Financial Statements

\begin{tabular}{|c|c|c|c|}
\hline $\begin{array}{l}\text { Lead-Time of } \\
\text { Publication }\end{array}$ & Frequency & Percentage & $\begin{array}{c}\text { Cumulative } \\
\text { Percentage }\end{array}$ \\
\hline $0-30$ & 1 & 1.00 & 1.00 \\
\hline $31-40$ & 1 & 1.00 & 2.00 \\
\hline $41-50$ & 9 & 9.00 & 11.00 \\
\hline $51-60$ & 10 & 10.00 & 21.00 \\
\hline $61-72$ & 37 & 38.00 & 59.00 \\
\hline $\mathbf{7 3}$ & $\mathbf{1 3}$ & $\mathbf{1 3 . 0 0}$ & $\mathbf{7 2 . 0 0}$ \\
\hline $74-80$ & 15 & 15.00 & 87.00 \\
\hline $81-90$ & 4 & 4.00 & 91.00 \\
\hline $91-100$ & 4 & 4.00 & 95.00 \\
\hline $101-110$ & 4 & 4.00 & 99.00 \\
\hline $111-120$ & 0 & 0.00 & 99.00 \\
\hline $121-130$ & 1 & 1.00 & 100.00 \\
\hline TOTAL & 99 & 100.00 & \\
\hline & & \multicolumn{2}{|l}{} \\
\hline
\end{tabular}

Source: author's own calculation.

As shown in Table 3-A about 59\% of the companies reported earlier than the expected $73^{\text {rd }}$ day after a company's financial year-end. Thirteen percent of the companies released their audited financial statements exactly on the $73^{\text {rd }}$ day. About $28 \%$ of the ISE listed companies reported late, with the maximum delay being 56 days. The analysis also shows that while the shortest lead time was as early as 14 , the longest was as late as 129 .

Tab. 3-B: Pattern of Publication Dates of Consolidated Audited Financial Statements

\begin{tabular}{|c|c|c|c|}
\hline $\begin{array}{l}\text { Lead-Time of } \\
\text { Publication }\end{array}$ & Frequency & Percentage & $\begin{array}{c}\text { Cumulative } \\
\text { Percentage }\end{array}$ \\
\hline $0-30$ & 0 & 0 & 0 \\
\hline $31-40$ & 0 & 0 & 0 \\
\hline $41-50$ & 3 & 2.68 & 2.68 \\
\hline $51-60$ & 8 & 7.14 & 9.82 \\
\hline $61-70$ & 15 & 13.40 & 23.22 \\
\hline $71-80$ & 12 & 10.71 & 33.93 \\
\hline $81-90$ & 15 & 13.40 & 47.33 \\
\hline $91-100$ & 21 & 18.75 & 66.08 \\
\hline
\end{tabular}


Türel, A. G.: Timeliness of Financial Reporting in Emerging Capital Markets: Evidence from Turkey.

\begin{tabular}{|c|c|c|c|}
\hline $\begin{array}{l}\text { Lead-Time of } \\
\text { Publication }\end{array}$ & Frequency & Percentage & $\begin{array}{c}\text { Cumulative } \\
\text { Percentage }\end{array}$ \\
\hline $\mathbf{1 0 1}$ & $\mathbf{2 0}$ & $\mathbf{1 7 . 8 5}$ & $\mathbf{8 3 . 9 3}$ \\
\hline $102-110$ & 17 & 15.17 & 99.10 \\
\hline $111-120$ & 1 & 0.90 & 100.00 \\
\hline TOTAL & 112 & 100.00 & \\
\hline
\end{tabular}

Source: author's own calculation.

As shown in Table 3-B about $66 \%$ of the companies reported earlier than the expected $101^{\text {st }}$ day after a company's financial year-end. About $18 \%$ of the companies released their audited financial statements exactly on the $101^{\text {st }}$ day. About $16 \%$ of the ISE listed companies reported late, with the maximum delay being 12 days. The analysis also shows that while the shortest lead time was as early as 43 , the longest was as late as 113 .

Tab. 4-A: Summary Statistics (Separate Financial Statements)

\begin{tabular}{|l|r|r|r|r|r|}
\cline { 2 - 7 } \multicolumn{1}{c|}{} & \multicolumn{5}{c|}{ Summary Statistics } \\
\hline Variables & Minimum & Maximum & Mean & $\begin{array}{l}\text { Standard } \\
\text { Deviation }\end{array}$ & $\%^{*}$ \\
\hline LEADTIME & 14 & 129 & 69.68 & 15.44 & \\
\hline SIZE & 2877495 & 3037876731 & 233689116 & 418125146 & \\
\hline AUDITOR & & & & & 39.39 \\
\hline INCOME & & & & & 71.72 \\
\hline OPINION & & & & & 83.84 \\
\hline INDUSTRY & & & & & 78.79 \\
\hline
\end{tabular}

Source: author's own calculation.

Table 4-A presents summary statistics of the variables used in this study. As is evident, it takes ISE listed companies (that prepares separate financial statements) approximately 70 days, on average, to report to the public after the end of their financial year-end. The standard deviation for the LEADTIME variable is 15 days, suggesting considerable variability in timely reporting by the companies. It is found that $39.39 \%$ of the sample was audited by big four audit firms and $71.72 \%$ of the companies audit report was standard. $83.84 \%$ of the companies report net income for the year 2007 and $78.79 \%$ of the companies were operating in the manufacturing industry. 
Tab. 4-B: Summary Statistics (Consolidated Financial Statements)

\begin{tabular}{|l|r|r|r|r|r|}
\cline { 2 - 7 } \multicolumn{1}{c|}{} & \multicolumn{5}{c|}{ Summary Statistics } \\
\hline Variables & Minimum & Maximum & Mean & $\begin{array}{r}\text { Standard } \\
\text { Deviation }\end{array}$ & $\%^{*}$ \\
\hline LEADTIME & 43 & 113 & 86.30 & 17.13 & \\
\hline SIZE & 11457411 & 9770052000 & 1012365604 & 1985386912 & \\
\hline AUDITOR & & & & & 45.54 \\
\hline INCOME & & & & & 75.89 \\
\hline OPINION & & & & & 84.82 \\
\hline INDUSTRY & & & & & 80.36 \\
\hline
\end{tabular}

Source: author's own calculation.

Table 4-B presents summary statistics of the variables used in this study. As is evident, it takes ISE listed companies (that prepares consolidated financial statements) 86 days, on average, to report to the public after the end of their financial year-end. The standard deviation for the LEADTIME variable is 17 days, suggesting considerable variability in timely reporting by the companies. It is found that $45.54 \%$ of the sample was audited by big four audit firms and $75.89 \%$ of the companies audit report was standard. $84.82 \%$ of the companies report net income for the year 2007 and $30.36 \%$ of the companies were operating in the manufacturing industry.

Tab. 4-C: Summary Statistics

\begin{tabular}{|l|r|r|r|r|r|}
\cline { 2 - 7 } \multicolumn{1}{c|}{} & \multicolumn{5}{c|}{ Summary Statistics } \\
\hline Variables & Minimum & Maximum & Mean & $\begin{array}{l}\text { Standard } \\
\text { Deviation }\end{array}$ & $\%^{*}$ \\
\hline LEADTIME & 14 & 129 & 78.50 & 18.32 & \\
\hline SIZE & 2877495 & 9770052000 & 647015024 & 104786332 & \\
\hline AUDITOR & & & & & 42.65 \\
\hline INCOME & & & & & 73.93 \\
\hline OPINION & & & & & 84.36 \\
\hline INDUSTRY & & & & & 79.62 \\
\hline
\end{tabular}

Source: author's own calculation. 
Türel, A. G.: Timeliness of Financial Reporting in Emerging Capital Markets: Evidence from Turkey.

Table 4-C presents summary statistics of the variables used in this study. As is evident, it takes ISE listed companies approximately 79 days, on average, to report to the public after the end of their financial year. The standard deviation for the LEADTIME variable is 18 days, suggesting considerable variability in timely reporting by the companies. . It is found that $42.65 \%$ of the sample was audited by big four audit firms and $84.36 \%$ of the companies audit report was standard. $73.93 \%$ of the companies report net income for the year 2007 and $79.62 \%$ of the companies were operating in the manufacturing industry.

Tab. 5: Table for Mean Differences for Dichotomous Variables

\begin{tabular}{|l|c|c|}
\hline LEADTIME & \multicolumn{2}{|c|}{ Independent Variables } \\
\hline & Big 4 Audit Firms & Others \\
\hline LEADTIME (Mean) & 80.76 & 76.83 \\
\hline Standard Deviation & 16.83 & 19.25 \\
\hline & Standard Opinion & Others \\
\hline LEADTIME (Mean) & 77.16 & 85.76 \\
\hline Standard Deviation & 18.48 & 15.78 \\
\hline & Net Income & Loss \\
\hline LEADTIME (Mean) & 76.25 & 84.87 \\
\hline Standard Deviation & 18.12 & 17.51 \\
\hline & Manufacturing & Others \\
\hline LEADTIME (Mean) & 78.43 & 78.77 \\
\hline Standard Deviation & 18.76 & 16.67 \\
\hline
\end{tabular}

Source: author's own calculation.

Table 5 shows the results from comparison of means between the dichotomous variables. From the table, it can be seen that on average, the delay in financial reporting increases with the presence of a loss, qualified audit opinion while reduces for companies audited by small audit firms. As for AUDITOR, the mean delay for Big 4 audit firms are higher by about 4 days than those for small audit firms with a mean delay of only 76 days. Regarding INCOME, companies suffering from losses seem to have a longer mean delay than those gaining a positive net income. Companies receiving a qualified audit opinion also seem to take on average of 8 days more than those receiving a clean audit report. However, there is no significant difference of the financial reporting delay between companies in manufacturing industry or other industries. 


\subsection{Regression Analysis}

The reporting obligations relating to timeliness of separate financial statements and consolidated financial statements of Turkish listed companies are different. Separate financial statements must be published not later than 73 days, and consolidated financial statements must be published not later than 101 days after the financial year end. This difference was eliminated in order not to reach incorrect regression results. Instead of days, a ratio was used as a dependent variable in regression analysis. In order to calculate this ratio, the lead time of financial statements were divided to obligatory date and the result was multiplied by hundred. For instance, if a company publishes its separate financial statements 45 days after the year end, the dependent variable is calculated as $61.64(45 / 73 \cdot 100)$

Tab. 6: Regression Model

\begin{tabular}{|c|c|c|}
\hline \multicolumn{3}{|c|}{ MODEL: $\begin{aligned} \text { LEADTIME }= & b_{0}+b_{1} \cdot \text { SIZE }+b_{2} \cdot A U D I T O R+b_{3} \cdot I N C O M E \\
& +b_{4} \cdot \text { OPINION }+b_{5} \cdot \text { INDUSTRY }+e\end{aligned}$} \\
\hline & Coefficient & t-value \\
\hline INTERCEPT & 87.19 & 21.027 \\
\hline SIZE & -1.23 E-009 & -1.421 \\
\hline AUDITOR & 5.687 & $2.128^{*}$ \\
\hline INCOME & -6.786 & $-2.215^{*}$ \\
\hline OPINION & -7.520 & $-2.037^{*}$ \\
\hline INDUSTRY & 12.385 & $3.944^{*}$ \\
\hline
\end{tabular}

\begin{tabular}{|l|r|}
\hline Summary of the Regression Output \\
\hline Sample Size & 211 \\
\hline F Ratio & 6.297 \\
\hline Significant F & 0.000 \\
\hline $\mathrm{R}^{2}$ & 0.133 \\
\hline Adjusted $\mathrm{R}^{2}$ & 0.112 \\
\hline
\end{tabular}

* Significant at 0.05

Source: author's own calculation.

Table 6 above presents the multiple regression results for the sample. As seen in the table, the F-statistic of model is significantly different from zero, indicating that a subset of the independent variables does explain the variation in LEADTIME about its mean. The value of the adjusted $\mathrm{R}^{2}$ 
Türel, A. G.: Timeliness of Financial Reporting in Emerging Capital Markets: Evidence from Turkey.

indicates that only $13 \%$ of the variation in LEADTIME is explained by the model. The coefficient estimates for AUDITOR, INCOME, OPINION and INDUSTRY are all statistically significant. Lead time was positively associated with AUDITOR, INDUSTRY and negatively associated with INCOME and OPINION. This means that lead time decreases with the presence of income and standard audit report. On the other hand, an increase in lead time was observed with Big 4 auditor firms and manufacturing industry. The SIZE coefficient is negative but statistically not significant.

It was also found that companies receiving a qualified audit opinion seem to suffer from a longer lead time than those receiving a standard (clean) audit report. Logically, it can be argued that auditors need to spend considerable amount of time and effort in pursuing audit procedures to confirm the qualification or maybe possibly to avoid such qualification. Manufacturing companies were hypothesized to have a longer lead time than other companies as the former normally have a higher level of inventory or fixed assets. As we know, the audit of inventory is normally the most time consuming and thus more tentative audit work is required. According to our results, the manufacturing industries report a longer lead time (12 days) than do the rest.

According to these results, companies that are audited by big four audit firms publish their financial statements 6 days later than other companies that are audited by relatively small audit firms. This result contradicts with the prior researches (Gilling, 1977; Williams et al., 1982). With the assumption that big four audit firms are more efficient and are more likely to have "on-going" audits than small companies, they found that companies audited by big four publish their financial statements earlier than other companies. Besides this, a study conducted in China ( $\mathrm{Ng}$ et al., 1994) reports similar results to this study. The small auditor companies will make special efforts to avoid delays in the auditing, with the result that the audit delay will be less for these auditors.

The other finding of this study is that companies that report net income for the period publish their financial statement 7 days earlier than other companies that report loss for the period. In addition, it is found that companies that have standard audit reports publish their financial statements 8 days earlier than other companies that have qualified or adverse opinions. Finally, this study finds that companies that are 
operating in the manufacturing industry publish their financial statements 12 days later than other industries.

The nature and degree of multicollinearity among the explanatory factors and LEADTIME were assessed. Table 7 presents the correlation matrix of the independent variables. Nevertheless, it seems that in this study, multicollinearity does not pose a problem in interpreting the regression results as the highest value of correlation is 0.30 represents the correlations between INCOME and OPINION.

Tab. 7: Pearson Correlation Matrix

\begin{tabular}{l|c|c|c|c|c|}
\hline Variables & SIZE & AUDITOR & INCOME & OPINION & INDUSTRY \\
\hline SIZE & 1 & & & & \\
\hline AUDITOR & $0.243^{*}$ & 1 & & & \\
\hline INCOME & $0.185^{*}$ & $0.141^{* *}$ & 1 & & \\
\hline OPINION & 0.049 & $0.213^{*}$ & $0.309^{*}$ & 1 & \\
\hline INDUSTRY & $-0.097^{* * *}$ & -0.039 & 0.075 & 0.041 & 1 \\
\hline
\end{tabular}
Significant at 0.01
** Significant at 0.05

Source: author's own calculation.

\section{Conclusions, Limitations and Implications for Future Research}

It is not only necessary that users have financial information which is relevant to their predictions and decisions; the information should also be current in nature rather than relating only to prior periods. The information used by investors and creditors should be current at the time of making the predictions and decisions. The accumulation and summarization of accounting information and its publication should be as rapid as possible to assure the availability of current information to the users. Timeliness is recognized as an important characteristic of accounting information by the accounting profession, the users of accounting information, and the regulatory agencies.

This paper investigates the effects of both company specific and audit related factors such as company size, sign of income, industry, audit opinion, and auditor firm on timely financial reporting practices in a developing country, Turkey. For this objective, financial statements and audit reports of 211 listed companies which are not operating in the 
Türel, A. G.: Timeliness of Financial Reporting in Emerging Capital Markets: Evidence from Turkey.

financial industry were analyzed. The descriptive analysis indicates that $59 \%$ of the companies that prepares separate financial statements and $66 \%$ of the companies that prepares consolidated financial statements release their financial statements less than the maximum time allowed after the financial year-end. $28 \%$ of the companies that prepares separate financial statements and $16 \%$ of the companies that prepares consolidated financial statements exceeded the regulatory deadline.

According to empirical results; $13.30 \%$ of the variation in the lead time in our model is explained by variations in company size, auditor firm, sign of income, audit opinion, and industry. The coefficient estimates for AUDITOR, INCOME, OPINION and SECTOR are all found statistically significant. The SIZE coefficient is found negative but statistically not significant.

The findings indicate that the companies that report net income, have standard audit opinion release their financial statements earlier. On the other hand, it is found that the companies that are audited by big four audit firms and operating in manufacturing industry are late reporters.

The analysis provides strong support for the notion that the financial statements are delayed when a loss is reported or a qualified opinion is given. The possibility is that management delays the reporting of bad news by delaying the financial statement. According to results, it can be argued that investors should expect a loss or a qualified audit opinion for the period if the company does not release its financial statements early. In addition, it can be said that small audit firms are making special efforts to avoid delays in the auditing. Since the big four audit firms in Turkey have a high number of customers it is not surprising that there have been some delay in their auditing.

While these conclusions are consistent with prior studies, they should be considered in the light of these limitations. First, the results may not be generalizable to financial companies listed because such companies were excluded from our sample. Second, this study did not consider all relevant factors that might affect timeliness in reporting. Finally, this study investigates the timely reporting behavior of ISE listed companies at a particular point in time. Future research may examine the same sample of companies over a period of time to ascertain the trend in their timely reporting behavior. 


\section{References}

[1] Abdulla, J. Y. A. (1996): The Timeliness of Bahraini Annual Reports. Advances in International Accounting, 1996, vol. 9, pp. 73-88.

[2] Ahmad, R. A. R. - Kamarudin, K. A. (2003): Audit Delay and the Timeliness of Corporate Reporting: Malaysian Evidence. Communication Hawaii International Conference on Business, University of Hawaii-West Oahu, 2003.

[3] Ansah, S. O. (2000): Timeliness of Corporate Financial Reporting in Emerging Capital Markets: Empirical Evidence from the Zimbabwe Stock Exchange. Accounting and Business Research, 2000, vol. 30, no. 3, pp. 241-254.

[4] Ansah, S. O. - Leventis, S. (2006): Timeliness of Corporate Annual Financial Reporting in Greece. European Accounting Review, 2006, vol. 15, no. 2, pp. 273-287.

[5] Ashton, R. H. - Willingham, J. J. - Elliot, R. K. (1987): An Emprical Analysis of Audit Delay. Journal of Accounting Research, 1987, vol. 25, no. 2, pp. 275-292.

[6] Ashton, R. H. - Graul, P. R. - Newton, J. D. (1989): Audit Delay and the Timeliness of Corporate Reporting. Contemporary Accounting Research, 1989, vol. 5, no. 2, pp. 657-673.

[7] Bamber, E. M. - Bamber, L. S. - Schoderbek, M. P. (1993): Audit Structure and Other Determinants of Audit Report Lag: An Emprical Analysis. Auditing: A Journal of Practice and Theory, 1993, vol. 12, no. 1, pp. 1-23.

[8] Bonson-Ponte, E. - Escobar-Rodriguez, T. - Borrero-Dominguez, C. (2008): Empirical Analysis of Delays in the Signing of Audit Reports in Spain. International Journal of Auditing, 2008, vol. 12, no. 2, pp. 129-140.

[9] Carslaw, C. - Kaplan, S. E. (1991): An Examination of Audit Delay: Further Evidence from New Zealand. Accounting and Business Research, 1991, vol. 21, no. 85, pp. 21-32.

[10] Courtis, J. K. (1976): Relationships between Timeliness in Corporate Reporting and Corporate Attributes. Accounting and Business Research, 1976, vol. 6, no. 4, pp. 204-219. 
Türel, A. G.: Timeliness of Financial Reporting in Emerging Capital Markets: Evidence from Turkey.

[11] Davies, B. - Whittred, G. P. (1980): The Association between Selected Corporate Attributes and Timeliness in Corporate Reporting: Further Analysis. Abacus, 1980, vol. 16, no. 1, pp. 48-60.

[12] Gilling, D. M. (1977): Timeliness in Corporate Reporting: Some Further Comment. Accounting and Business Research, 1977, vol. 7, no. 4 , pp. 35-50.

[13] Givoly, D. - Palmon, D. (1982): Timeliness of Annual Earnings Announcements: Some Empirical Evidence. Accounting Review, 1982, vol. 57, no. 3, pp. 485-508.

[14] Haw, I. -Qi, D. - Wu, W. (2000): Timeliness of Annual Report Releases and Market Reaction to Earnings Announcements in an Emerging Capital Market: The Case of China. Journal of International Financial Management and Accounting, 2000, vol. 11, no. 2, pp. 108-131.

[15] Hossain, M. A. - Taylor, P. (1998): An Examination of Audit Delay: Evidence from Pakistan, Working Paper. 1998, University of Manchester, 1998.

[16] Newton, J. D. - Ashton, R. H. (1989): The Association between Audit Technology and Audit Delay. Auditing: A Journal of Practice \& Theory, 1989, vol. 8, no. 1, pp. 22-37.

[17] Ng, P. P. - Tai, B. Y. K. (1994): An Empirical Examination of the Determinants of Audit Delay in Hong Kong. British Accounting Review, 1994, vol. 26, no. 1, pp. 43-59.

[18] SPK (1989): Sermaye Piyasası Kurulu, Seri: XI, No. 1 "Sermaye Piyasasında Mali Tablo ve Raporlara İlişkin İlke ve Kurallar Hakkında Tebliği”, Resmi Gazete, $29^{\text {th }}$ January, 1989.

[19] SPK (2003): Sermaye Piyasası Kurulu, Seri: XI, No. 25 "Sermaye Piyasasında Muhasebe Standartları Hakkında Tebliği”. Resmi Gazete, $15^{\text {th }}$ November, 2003.

[20] SPK (2008): Sermaye Piyasası Kurulu, Seri: XI, No: 29 "Sermaye Piyasasında Finansal Raporlamaya İlişkin Esaslar Tebliği”. Resmi Gazete, $9^{\text {th }}$ April, 2008.

[21] Türk Ticaret Kanunu (1956). Resmi Gazete, $9^{\text {th }}$ July, 1956.

[22] Williams, D. D. - Dirsmith, M. W. (1988): The Effects of Audit Technology on Auditor Efficiency: Auditing and the Timeliness of Client Earnings Announcements. Accounting, Organizations and Society, 1988, vol. 13, no. 5, pp. 487-508. 


\title{
Timeliness of Financial Reporting in Emerging Capital Markets: Evidence from Turkey
}

\author{
Asli Gunduzay TÜREL
}

\begin{abstract}
Timely financial reporting is an essential ingredient for a well-functioning capital market. The objectives of this study are two-fold. First, to measure the extend of timeliness in a developing country, Turkey. Second, to establish the impact of both company specific and audit related factors on timeliness of financial reporting in Turkey. This study reports on the results of an empirical investigation of the timeliness of financial reports by 211 non-financial companies listed on the Istanbul Stock Exchange. The descriptive analysis indicates that $59 \%$ of the companies that prepares separate financial statements and $66 \%$ of the companies that prepares consolidated financial statements release their financial statements less than the maximum time allowed after the financial yearend. $28 \%$ of the companies that prepares separate financial statements and $16 \%$ of the companies that prepares consolidated financial statements exceeded the regulatory deadline. The multivariate regression analysis indicates that both sign of income, audit opinion, auditor firm and industry affect timeliness. The findings indicate that the companies that report net income, that have standard audit opinion, and that are operating in manufacturing industry release their financial statements earlier. On the other hand, it is found that the companies that are audited by big four audit firms are late reporters.
\end{abstract}

Key words: Timeliness; Financial Reporting; Accounting; Turkey.

JEL classification: M4, M40, M41. 